\title{
Digital Marketing during COVID 19: Consumer's Perspective
}

\author{
KHALED (M.K) ISMAIL ALSHAKETHEEP \\ Al-Hussein Bin Talal University, JORDAN \\ ALI A. SALAH \\ Business Department, \\ College of Business and Economics Business \\ Al-Hussein Bin Talal University, JORDAN \\ KHALID MOHUMMED ALOMARI \\ Business Department, College of Business and Economics Business \\ Al-Hussein Bin Talal University, JORDAN \\ AMGAD S. D. KHALED \\ Department of Management Information System \\ Al-Rowad University, Taiz, YEMEN \\ AHMAD ABDULLAH ABU JRAY \\ Al-Hussein Bin Talal University, JORDAN
}

\begin{abstract}
In this article, we present a first study on how Covid-19 pandemic can influence fundamental essences and marketing developments. We argue that Covid-19 pandemic offers businesses an excellent opportunity to shift to real and honest marketing that can actually tackle urgent environmental and social challenges globally. We also explore some future paths for how the pandemic can affect consumer ethical decision-making. In our marketing discussion, we explain how we think that marketing is being carried out and how we expect this pandemic can change, and not just the marketing climate, but also how companies implement their marketing strategies. We further discuss about the digital marketing during the pandemic how it can help the consumers. The data was collected from 500 consumers in Amman, Jordan so as to assess their perspective towards digital marketing. It was found out that consumers during the pandemic were attracted towards offers, anti-crisis deals, personalized digital communication and empathy by the companies.
\end{abstract}

Keywords: marketing, digital marketing, consumer's perspective, covid 19

Received: March 26, 2020. Revised: August 29, 2020. Revised: September 3, 2020. Accepted: September 7, 2020. Published: September 9, 2020.

\section{Introduction}

The latest coronavirus is spreading at such a high pace that it is difficult to determine as to when it will end. During the first shutdown in the United Kingdom we write this article and become the "responsible men." While scholars like ours are still busy studying on a regular basis, we learn how to adapt to a new reality and way of working (and life, given reduced lock-in constraints) by means of online meetings with colleagues and researchers, and obviously also by means of online teaching. Nonetheless, we will do so without advance notice or planning. Perhaps one of the main ways to resolve this lock-down is to use the situation to 
reflect on what we like most during our research, in our case corporate social responsibility (CSR) and marketing. What we think is the developing world. Unlike other major global incidents, Covid-19 profoundly altered how we see the environment, how we perceive and how we live. In the human drama of lost lives, fractured families and scarred cultures, a profound fact for us and future generations will be the economic and social pandemic lockout. Physical, psychological, social and economic pain. Covid-19 is seen in many ways as similar to what Taleb calls a "black swan occurrence" (as many writers and academics have experienced in the same way), Mazzoleni et al ., 2020. While Taleb (2008) a number of incidents in the past were discussed (such as the 911 events), his work shows that human reactions to such shocks appear to reverse critical forecasts. [10] Within the shocking culture , people rationalize aftershocks that alter society almost instantly, meaning that they have been expected and therefore prevented. Was Covid-19 an example - we assume so? It can only conclude that a potential pandemic can be avoided by studying the lessons and by conspiracy theorists and government opportunists in the midst of endless dystopian media. You can only believe that until Covid 19 we will be educated. [5]

And Covid-19 has an unprecedented effect on the global economy after the Great Depression in the 1930's. [4] Therefore, the Covid-19 pandemic certainly represents a significant environmental change in contemporary marketing history and will impact corporate social responsibility (CSR), consumer ethics and the fundamental marketing theory. Despite the wide foreign shutdowns and social gaps, the short-term consequences of Covid-19 are felt immediately and easily. Nevertheless, the pandemic ends and still has significant social, political and cultural implications for a long time. Within this paper we discuss some basic ideas about how the CSR and marketing theory can affect this pandemic. As far as CSR is concerned, we will discuss its effect on CSR benefits, patterns and consumer ethics. We will concentrate on its potential effect on key marketing principles, business circumstances and marketing strategies.

\section{Core Marketing Concepts}

The massive and profound upheaval of the Covid 19 pandemic would have a multiple impact on marketing discipline. The philosophies, values and basic concepts that drive our profession often affect the way our lives and cultures are uprooted, changed and influenced by events. Although much of this shift is hard to foresee, these developments are likely to have a significant effect on core marketing practices, thought and concepts. Marketing is based on a marketing strategy theory and methodology, in which we aim to define and react better than rivals to the requirements and preferences of the target audiences.[8] More educated, progressive voices and organizations have spoken out for changes in the definition of corporate marketing whereby corporations balance short-term customer needs in terms of long-term social well-being. [7] \& [8] After Covid-19, customers, communities and organisations will undoubtedly reassess these ideologies and goals critically. Economists, theorists and advertisers were mainly concerned with long-termism while "real-world" constraints limited more immediate and urgent issues for politicians, businesses and managers. Through this context, the ultimate and short-term goals have been promoted over longer-term, more ethereal goals.[2] Can a pandemic provide marketing directors and researchers with ample shock to challenge their businesses and their own core strategies and underlying ideologies? It's hard to predict at this point, but as the death rate increases and we all face the post-pandemic world, socially marginalized, lock-down practitioners and academics have a lot of 
time to reflect on the importance and relevance of their lives and businesses. Marketers have also promoted the benefits of identifying and generating positive consumer interest, satisfaction and loyalty assessments. In reality, over the past half a century, many marketing 101 modules and countless consultants' programs and professions have been transformed into a credo of consumer autonomy that encourages constructive consumer perceptions and perspectives on product offerings. However, mid-pandemic customers did not focus on the considered judgments of various brands or long-term interest or potential loyalty reflections, but frustratingly restricted limited choice, exposure to goods and immediate demand. In certain cases, rather than marketing myopia, while advertisers are focused on the actual features of their goods, they are not looking at latent desires of consumers. The Corvid pandemic was more of the consumer pandemic dream of panic purchasing and hoarding (Lewis, 2020), while advertisers will likely be reproved and disciplined for their products in the future. Retrospective analyses of these actions and crisis management by organizations would certainly have a clear insight into these issues. Theorists and practitioners after the pandemics will potentially face a drastically different marketing world and clients. Opinions, opinions, principles, attitudes and behaviors are changing as a result of good and poor experiences, but unfortunately the outbreak of Covid 19 has had a significant effect on all of these. PreCovid, marketers are driven to maximize their customer interest effectively and efficiently by means of consumer loyalty, market / customer share, and customer equity. There may be critical questionings regarding post-pandemic, historically normal and apparently indiscriminate metrics, such as consumer lifetime value, market share and customer equity. While it seems unlikely that these tests will be completely ignored, it seems likely that advertisers and consumers will adjust and complement these steps. Although some far-sighted analysts have long argued the marketing climate is rebounding (Potts 2018), the Covid 19 crisis seems to have massively exacerbated the changes, and the planet after the pandemic is going to experience several wounds that heal needless scarves. The essence of marketing can be seen as an exchange. The interactions rely on mutual understanding, interest appreciation and communication both of which were dramatically changed during the Covid-19 events for many purchasers and suppliers. Most governments shortened the supremacy of face to face meetings and transactions, which were gradually (in many contexts) undermined by online communication. Politicians and social scientists, many of whom had previously blamed clients for leaving high street shops and centers, modified their views on the internet market so that they acknowledged that there should have been 2 or 3 or more significant impacts of these pandemics on the Internet. The relationship between buyers and suppliers suddenly changed when lock-ins were enforced and restrictions on travel enforced. In the past few years, the new era of internet, smartphones and social media marketing has risen from pre-adolescence to a turbulent teenager. Skype, WhatsApp and Zoom (and several more). In future studies these things must be mapped and deconstructed as the world after the pandemic is very different.

\section{The business sense}

While adjustments to core marketing principles have been and continue to be made, these changes reflect the disruption Covid-19 caused in the marketing environment. Recessions, downturns, wars, revolutions, earthquakes and volcanoes have appeared to have been small prejudices compared to regional blockades or broad-based, non-millennium state interventionism. 
A transitional tsunami has entered the marketing microenvironments of organizations which go beyond previous volatility and consequences. The way businesses work has been changed by social alienation and forced lockouts that require drastic changes in processes and structures. Through lock-downs and local supply chains distributed across most industries and markets, the global supply chain has become highly fragmented. Distribution firms have gone from being known as "brown truck pests and wretched nuisances" to being almost starved by the customer as domestic saviors for goods (SIRC, 2020; see Hatchman). Restaurants around the globe have become receptionists from great restaurants, fast food suppliers have expanded their role to supermarket shoppers and suppliers (see Whitbread, 2020). In periods of months and years of past initiatives, advertisement and media organizations needed approaches and responses. Public security campaigns and other social media campaigns, and lessons learned and accepted from new ideas and practical perspectives will be discussed. The sense of business has also shifted. Following this pandemic, consumers, the public and the government required and sometimes forced collaboration to help all. In this regard, the former rivals are now automatically allies - an example of Formula 1 's unparalleled effort to create, manufacture and supply fans (see de Menzies, 2020). Post-pandemic retrospective research would investigate the advantages and rewards of cooperation embodied by practitioners in previous adversary organisations.

The marketing macro climate has changed profoundly and will have a repercussion for decades. The global economy has been seriously affected. Covid 19 initiatives have diminished the impact of austerity programmes, shut down entire markets, forced companies to migrate almost completely online and dramatically changed the essence of consumer spending. In particular, food retailers had incomparable sales prior to locks while massive demand flourished among online entertainment and networking organizations. Some sectors such as building and the automotive industry have been seriously hit and waves and returns on demand and supply can fluctuate over many years. Politically, nearly every country has undergone significant changes in philosophies that, among many other issues, have strongly extended previously sought after theories of freedom of movement and the market economy. In many countries the State has taken on many industries and the impact on nations, regions and global economies will reverberate in the long term. Technology usually used to replace personal communication, even as policy makers hailed the Web as a lifesaving tool (in countries that are tracking viruses, especially in Asia) (the Japan Times, 2020). Press reports have also suggested that in 24 hours 20 years of development in technology have been turned into a pandemic. Science and technology became a priority as scientists, modelers and scientists were given immediate funding to explore vaccines, antibody testing and virologic modelling. Covid-19 has changed socially and will change people's mind and behaviors, companies, executives and governments. Cultural shifts have taken place in people's views of themselves, others, institutions, nature and the environment. Whereas the timetable of such events was little anticipated, prospective scientists and long-term scenario planners have sought to stress the possible effect of these drastic and devastating events on the earth (see Malaska 2000). Which exactly will be the essence of these shifts in our climate and culture?

\section{Digital Marketing}

Digitalising or integrating digital media into the operation of an organization includes digitalization and the 
incorporation of telecommunications, Internet and mobile technology to transform contact between consumers , suppliers, and channel partners. [3] [13] The Global Development Report on Digital Dividends (World Bank 2016) states that while digitalization is a major trend, customer organizations withdraw from digital adoption. The downside to digitisation is due to inadequate digital advancements and skills, [6] undefined digital efficiency benefits [9] and transformation processes in organizational and international businesses (IP) (Overby and Min, 2001; Digitalization provides new sources of value through the partnership capability process and complementarity of services that organizations, suppliers and customers, gain by reconfiguring services. Weill and Woerner (2015) suggest that companies should develop digitalization as an ecosystem rather than a linear value chain. For instance, Amazon is an ecosystem which connects and relies on each other, suppliers and distributors. Customers can compare, compare, and use the Amazon supply or direct seller stock. Brand feedback, customer insights, and industry awareness are accessible to Amazon vendors. [12]

The flow of information generated by through Web and mobile devices worldwide pushes businesses to learn new ways to process a wide range of information, acquire company expertise and get customers interested online. Companies also seek to preserve and use the data collected from their customer information systems (Stein et al . 2013), which means that digitisation requires often a revision of conventional business models. [9] Prasad and al. (2001) argue that Internet integration and marketing change the roles of export marketing. For example, the Internet helps the company to communicate directly with customers, suppliers or alliance partners instead of depending on intermediaries. Day (2011) believes that businesses that continue to achieve success will increase their direct engagement with digital users and create a seamless network of customers, suppliers and partners. Some more relevant studies can be found. [14] [15]

\section{According to Deloitte}

Digital Sales Are Becoming More Active Than Holiday Period

- Cohesive networks and customer service are more critical than ever in the current setting, as non-essential companies are shutting doors to stop the spread of Covid-19. This meant that both retailers and consumers had to turn to digital reality overnight.

- Digital revenues in Q1 2020 are 18 percent higher than in Q1 2019

- Traffic production in Q1 2020 is 13 percent relative to Q1 2019.

- Mobile and Social Increase in Traffic There are two more peculiar patterns, in addition to the growth in digital commerce and traffic

- The first involves traffic on the monitor. In Q1 2019, mobile traffic declined by $9 \%$, but in Q1 2020 it increased by $9 \%$. There is a marked turn to internet traffic and transactions of people inside and not going.

- Another trend is that social media traffic has risen rapidly. In the first quarter of 2019, the share of social network transport was 6 percent. This rose to 8 percent for the first quarter of 2020 .

\section{Research Methodology}

To assess the impact of COVID 19 on the consumer behaviour, an online survey was conducted. A concise analysis was carried out after the assessment of various responses. The Likert scale was used to allow participants to reply to particular questions and indicate whether or they have a viewpoint. The survey was distributed to 500 consumers residing in Amman, Jordan, since it has been a new 
normal in the world the responses were varying. The reason behind varying responses was that the consumers were trying to adjust to this new normal. The sampling technique adopted was snowball sampling. For the analysis descriptive, ANOVA, independent sample $t$ test and regression was used. For the rest of the analysis it was shown with the help of pie charts as to what consumers perceptions regarding their buying behaviour are.

\section{Distribution of Results}

There have been 500 absolute and open responses collected from various regions in Amman, Jordan.

Table 1: Demographics of the respondents

\begin{tabular}{|c|c|c|}
\hline Variable & $\begin{array}{c}\text { Total } \\
\text { Responses }\end{array}$ & Percentage \\
\hline \multicolumn{3}{|c|}{ Gender } \\
\hline Male & 176 & 35.2 \\
\hline Female & 324 & 64.8 \\
\hline \multicolumn{3}{|c|}{ Age } \\
\hline $20-30$ & 320 & 64 \\
\hline $30-40$ & 170 & 34 \\
\hline $40-50$ & 8 & 1.6 \\
\hline 50 and above & 2 & 0.4 \\
\hline \multicolumn{3}{|c|}{ Occupation } \\
\hline Student & 300 & 60 \\
\hline Employed & 130 & 26 \\
\hline Others & 30 & 6 \\
\hline Government Employee & 40 & 8 \\
\hline
\end{tabular}

\section{Demographics Highlights}

- Female respondents were higher than the male respondents.

- Majority of the respondents were in the age group of 20-30 years old.

- Majority of the respondents were students.
Table 2: ANOVA results for Impact of Demographics on the Attraction towards offers

\begin{tabular}{|c|c|c|c|c|c|c|}
\hline & Type & Number & Mean & F & Sig & Result \\
\hline \multirow{2}{*}{ Gender } & Male & 176 & 3.987 & \multirow{2}{*}{1.712} & \multirow{2}{*}{0.126} & \multirow{2}{*}{ sig } \\
\hline & Female & 324 & 3.467 & & & \\
\hline \multirow{4}{*}{ Age Group } & $20-30$ & 320 & 2.991 & \multirow{3}{*}{3.821} & \multirow{3}{*}{0.006} & \multirow{3}{*}{$\begin{array}{l}\text { No } \\
\text { sig }\end{array}$} \\
\hline & $30-40$ & 170 & 3.456 & & & \\
\hline & $40-50$ & 8 & 3.212 & & & \\
\hline & $\begin{array}{l}50 \text { and } \\
\text { above }\end{array}$ & 2 & 2.311 & & & \\
\hline \multirow{4}{*}{ Occupation } & Student & 300 & 2.958 & \multirow{4}{*}{2.621} & \multirow{4}{*}{0.000} & \multirow{4}{*}{$\begin{array}{l}\text { No } \\
\text { Sig }\end{array}$} \\
\hline & Employed & 130 & 3.006 & & & \\
\hline & Others & 30 & 2.926 & & & \\
\hline & $\begin{array}{l}\text { Government } \\
\text { Employee }\end{array}$ & 40 & 2.830 & & & \\
\hline
\end{tabular}

1. Gender: The results show that there is a significant difference between attracted towards offers of males vis a vis to females. The mean value shows that the females were attracted towards offers on various digital platforms during the pandemic

2. Age Group: There is no significant difference between attracted towards offers and age group of the consumers. The mean value shows that customers in the age group of 20-30 were attracted towards offers on various digital platforms during the pandemic

3. Occupation: There is a no significant difference between attracted towards offers and the occupation of the consumers. The consumers who were students were attracted towards offers on various digital platforms during the pandemic.

Table 3: ANOVA results for the impact on the anti-crisis deals

\begin{tabular}{|c|c|c|c|c|c|c|}
\hline & Type & Number & Mean & $\mathrm{F}$ & Sig & Result \\
\hline \multirow{2}{*}{ Gender } & Male & 176 & 3.987 & \multirow{2}{*}{2.987} & \multirow{2}{*}{0.001} & \multirow{2}{*}{$\begin{array}{l}\text { No } \\
\text { sig }\end{array}$} \\
\hline & Female & 324 & 3.467 & & & \\
\hline \multirow{4}{*}{ Age Group } & $20-30$ & 320 & 2.991 & \multirow{3}{*}{2.543} & \multirow{3}{*}{0.006} & \multirow{3}{*}{$\begin{array}{l}\text { No } \\
\text { sig }\end{array}$} \\
\hline & $30-40$ & 170 & 3.456 & & & \\
\hline & $40-50$ & 8 & 3.212 & & & \\
\hline & $\begin{array}{l}50 \text { and } \\
\text { above }\end{array}$ & 2 & 2.123 & & & \\
\hline \multirow{4}{*}{ Occupation } & Student & 300 & 2.958 & \multirow{4}{*}{2.769} & \multirow{4}{*}{0.029} & \multirow{4}{*}{ Sig } \\
\hline & Employed & 130 & 3.006 & & & \\
\hline & Others & 30 & 2.926 & & & \\
\hline & $\begin{array}{l}\text { Government } \\
\text { Employee }\end{array}$ & 40 & 2.830 & & & \\
\hline
\end{tabular}


The anti-crisis deals are those type of deals which are offered to consumers during the time the country is facing a crisis for example in grocery items they get super saver discounts.

1. Gender: The results show that there is a significant difference between anticrisis deals on males vis a vis to females. The mean value shows that the females tend to get attracted towards anti-crisis deals.

2. Age Group: There is a significant difference between anti-crisis deals and age group of the consumers. The mean value shows that customers in the age group of 30-40 tend to attract more towards anti-crisis deals

3. Occupation: There is a significant difference between anti-crisis deals and the occupation of the consumers. The consumers who were employed were attracted towards anti-crisis deals.

Table 4: ANOVA Results on the impact of Personalized Digital Communications

\begin{tabular}{|c|c|c|c|c|c|c|}
\hline & Type & Number & Mean & $\mathrm{F}$ & Sig & Result \\
\hline \multirow{2}{*}{ Gender } & Male & 176 & 3.213 & \multirow{2}{*}{3.765} & \multirow{2}{*}{0.000} & \multirow{2}{*}{ sig } \\
\hline & Female & 324 & 3.543 & & & \\
\hline \multirow{4}{*}{ Age Group } & $20-30$ & 320 & 2.503 & \multirow{4}{*}{3.309} & \multirow{4}{*}{0.049} & \multirow{4}{*}{ sig } \\
\hline & $30-40$ & 170 & 3.987 & & & \\
\hline & $40-50$ & 8 & 3.111 & & & \\
\hline & $\begin{array}{l}50 \text { and } \\
\text { above }\end{array}$ & 2 & 2.098 & & & \\
\hline \multirow{4}{*}{ Occupation } & Student & 300 & 2.958 & \multirow{4}{*}{3.987} & \multirow{4}{*}{0.002} & \multirow{4}{*}{ Sig } \\
\hline & Employed & 130 & 3.006 & & & \\
\hline & Others & 30 & 2.926 & & & \\
\hline & $\begin{array}{l}\text { Government } \\
\text { Employee }\end{array}$ & 40 & 2.830 & & & \\
\hline
\end{tabular}

1. Gender: The results show that there is significant difference between Personalized Digital Communications and gender of the consumers. The mean value shows that the males tend to get attracted more towards Personalized Digital Communications

2. Age Group: There is a significant difference between Personalized Digital Communications and age group of the consumers. The mean value shows that customers in the age group of $30-40$ tend to attract more towards Personalized Digital

\section{Communications.}

3. Occupation: There is significant difference between Personalized Digital Communications and the occupation of the consumers. The consumers who were employed are attracted towards Personalized Digital Communications

Table 4: ANOVA Results on the impact of Empathy

\begin{tabular}{|c|c|c|c|c|c|c|}
\hline & Type & Number & Mean & $F$ & Sig & Result \\
\hline \multirow{2}{*}{ Gender } & Male & 176 & 3.213 & \multirow{2}{*}{3.765} & \multirow{2}{*}{0.042} & \multirow{2}{*}{ Sig } \\
\hline & Female & 324 & 3.543 & & & \\
\hline \multirow{4}{*}{ Age Group } & $20-30$ & 320 & 2.503 & \multirow{4}{*}{3.309} & \multirow{4}{*}{0.049} & \multirow{4}{*}{ Sig } \\
\hline & $30-40$ & 170 & 3.987 & & & \\
\hline & $40-50$ & 8 & 3.111 & & & \\
\hline & $\begin{array}{l}50 \text { and } \\
\text { above }\end{array}$ & 2 & 2.098 & & & \\
\hline \multirow{4}{*}{ Occupation } & Student & 300 & 2.958 & \multirow{4}{*}{3.987} & \multirow{4}{*}{0.129} & \multirow{4}{*}{$\begin{array}{l}\text { No } \\
\text { Sig }\end{array}$} \\
\hline & Employed & 130 & 3.006 & & & \\
\hline & Others & 30 & 2.926 & & & \\
\hline & $\begin{array}{l}\text { Government } \\
\text { Employee }\end{array}$ & 40 & 2.830 & & & \\
\hline
\end{tabular}

1. Gender: The results show that there is significant difference between empathy shown through digital marketing and gender of the consumers. The mean value shows that the females tend to get attracted towards messages of empathy.

2. Age Group: There is a significant difference between empathy and age group of the consumers. The mean value shows that customers in the age group of 30-40 tend to get attracted towards messages of empathy.

3. Occupation: There is no significant difference between empathy and the occupation of the consumers. The consumers who were employed got attracted towards messages of empathy.

\section{Regression}

Table 5: Regression Results

\begin{tabular}{|c|c|c|c|c|c|}
\hline $\begin{array}{l}\text { S. } \\
\text { No }\end{array}$ & $\begin{array}{c}\text { Independent } \\
\text { variable }\end{array}$ & $\begin{array}{c}\text { Dependent } \\
\text { variable }\end{array}$ & Coefficient & sig & Result \\
\hline 1 & $\begin{array}{c}\text { Attraction } \\
\text { towards offers }\end{array}$ & \multirow{4}{*}{$\begin{array}{l}\text { Consumer } \\
\text { Behavior }\end{array}$} & 0.512 & 0.000 & Significance \\
\hline 2 & Anti-crisis deals & & 0.041 & 0.031 & Significance \\
\hline 3 & $\begin{array}{c}\text { Personalized } \\
\text { Digital } \\
\text { Communications }\end{array}$ & & 0.349 & 0.002 & Significance \\
\hline 4 & Empathy & & 0.325 & 0.000 & Significance \\
\hline
\end{tabular}


1. Table shows that there is significant difference between attraction towards offers and consumer's preference, the reason can be that during this pandemic the customers are not able to visit stores where usually there used to be sales and offers available for them. Since now they are being sent various offers through different digital marketing platforms they get attracted towards those offers

2. There is a significant difference between anti-crisis deals and consumer's preference, the reason can be that the customers are going through such a pandemic and they are stressed out because of it, so if they see any anticrisis deals they get attracted towards them and purchase it.

3. Above table shows that the personalized digital communication has a significant impact on the consumer's preference, the reason is that during these stressful times if a consumer is getting personalized communications from the companies they tend become loyal towards that company.

4. There is a significant difference between empathy and consumer's preference. The consumers prefer the companies to show some empathy towards them, they should listen to their customers and show fulfil their needs and wants accordingly during the pandemic.

\section{Exploratory Factor Analysis}

The primary purpose of factor analysis is the quantification and understanding of results. The Exploratory Factor Analysis (EFA) was conducted using the Principal Component Analysis (PCA) with varimax rotation for data reduction and a fairly large collection of variables. The EFA defines the clusters of strongly correlated objects within a single element. The number of products were calculated on the basis of the own value of more than 1 and the commonality of more than 0.5 . The relationship between various variables can be described in a set of fundamental parameters defined as "part" or "dimensions." An exploratory factor analysis ( EFA) was used to facilitate original variables definitions in fewer variables or parameters.

The load factor for each vector is shown in the following segment. 0.3 or higher factor loading shall be considered appropriate for psychometric purposes. There were 20 products selected based on the loading factor values.

\section{Reliability Analysis}

Reliability was calculated in order to test the internal consistency of the constructs, which is the inter-relationship between the elements of the construct making the scale. [16] Cronbach's Alpha is the most commonly used method for measuring the internal accuracy of the design and provides a numerical reliability coefficient. [17] The value of reliability higher than 0.70 is assumed to be ideal for calculating accuracy. Reliability estimates have been determined for each build and for the whole scale utilizing Cronbach's alpha and both values have been found to be higher than 0.80, which indicates the high reliability of the scale.

Table 7: Cronbach Alpha

\begin{tabular}{|l|c|c|}
\hline \multicolumn{1}{|c|}{ Construct } & $\begin{array}{c}\text { Cronbach } \\
\text { Alpha }\end{array}$ & $\begin{array}{c}\text { Overall } \\
\text { Cronbach } \\
\text { Alpha }\end{array}$ \\
\hline Attracting towards offers & .879 & \multirow{2}{*}{.804} \\
\cline { 1 - 2 } Anti-crisis deals & .762 & \\
\cline { 1 - 2 } $\begin{array}{l}\text { Personalized Digital } \\
\text { Communication }\end{array}$ & .901 & \\
\hline Empathy & .769 & \multirow{2}{*}{} \\
\hline
\end{tabular}

Confirmatory Factor Analysis (CFA) Measurement Model

The competitive benefit is to work with a rival. [18] [19] This needs the ability, which is the result of specific policy decisions, to distinguish the company from its peers. [20] Scientific literature was very comprehensive as the main competitor in price / cost - efficiency, delivery and usability. [21] [22] [23] Nonetheless, 
recent studies have identified profitability as a competitive target over time.

\section{Table 8: CFA Results}

\begin{tabular}{|l|c|c|}
\hline \multicolumn{1}{|c|}{ Fit Index } & Recommended Value & Value \\
\hline Chi-Square/ df & $<3.0$ & 2.12 \\
\hline GFI & $>.80$ & 1.20 \\
\hline AGFI & $>.80$ & 1.08 \\
\hline RMSEA & $<.07$ & 0.04 \\
\hline CFI & $>.80$ & 1.98 \\
\hline RMR & $<.01$ & .176 \\
\hline
\end{tabular}

\section{Conclusion}

Despite constant changes, improved communication for both consumers and employees is important. However, corporations ensure that a consistent message is transmitted through all channels and even points of communication. There are also those who open up new communication networks and expect to attract whole new audiences. Miss Fresh, an online retailer in China, says it has seen a $237 \%$ rise in users 40 years and older since the outbreak started. New digitally engaged customers develop specific standards and new opportunities to build trust and relevance. For example, advanced search features with functions such as dynamic range development enable users to define their own product experience. Hearing and tracking of shortage goods and offering sufficient alternatives or fair return times or drawing on alternate stocks and offering shut-down facilities offer a differentiated level of customer support and comfort. Direct consumers must contend with other unknowns including volatile transactions across diverse networks, such as new household purchasers. Due to the lack of historical proof for direct decisions, what to do next may be ambiguous. Brands listen more closely and use social and customer data as a method to recognize new demands and personalize their brand. Grocery stores worldwide are changing their way of working to meet consumer demands. Most businesses have equipped their customers with crisis-related facilities that display sincere empathy for the problems that so many face. This study can help the e- retailers, and the academicians. With the help of this study the retailers can know what type of products are the consumers looking for and what do they expect from the brands to do during the pandemic. The academicians can use this study for developing further studies post pandemic and to evaluate how the pandemic impacted during and post the virus spread.

\section{Reference}

[1]. Abbruzzese, J., Ingram, D., \& Click, S. (2020). The coronavirus pandemic drove life online. It may never return: What passes for normal life now happens almost entirely online. NBC News, 28th March.

[2]. Anwar Y. and El-Bassiouny N. (2020) Marketing and the Sustainable Development Goals (SDGs): A Review and Research Agenda. In: Idowu S., Schmidpeter R., Zu L. (eds) The Future of the UN Sustainable Development Goals. CSR, Sustainability, Ethics \& Governance. Springer, Cham

[3]. Coreynen, W., Matthyssens, P. and Van Bockhaven, W. (2017), "Boosting servitization through digitization: pathways and dynamic resource configurations for manufacturers", Industrial Marketing Management, Vol. 60, pp. 42-53.

[4]. Euronews (2020), 'COVID-19: World economy in 2020 to suffer worst year since 1930s Great Depression, says IMF', accessible at: https://www.euronews.com/2020/04/ 14/watch-live-internationalmonetary-fund-gives- worldeconomic-outlook-briefing-oncovid-19, accessed 06 May, 2020.

[5]. Grech, Victor (2020). "Unknown unknowns - COVID-19 and potential global mortality", Early Human Development, 144, May 2020, doi.org/10.1016/j.earlhumdev.2020.105026 
[6]. Kane, G.C., Palmer, D., Phillips, A.N. and Kiron, D. (2015), "Is your business ready for a digital future?", MIT Sloan Management Review, Vol. 56 No. 4, p. 37.

[7]. Kotler, P. and G. Zaltman (1971). 'Societal Marketing: An Approach to Planning Social Change', Journal of Marketing, 35, 3, 3-12.

[8]. Kotler, P., G. Armstrong, L. C. Harris and H. He (2019). Principles of Marketing, (European Edition), London, Prentice Hall.

[9]. Leeflang, P.S., Verhoef, P.C., Dahlstr€om, P. and Freundt, T. (2014), "Challenges and solutions for marketing in a digital era", European Management Journal, Vol. 32 No. 1, pp. 1-12.

[10]. Prasad, V.K., Ramamurthy, K. and Naidu, G.M. (2001), "The influence of internet-marketing integration on marketing competencies and export performance", Journal of International Marketing, Vol. 9 No. 4, pp. 82-110.

[11]. Taleb, N. (2008). The Black Swan: The Impact of the Highly Improbable, Penguin, London.

[12]. Weill, P. and Woerner, S.L. (2015), "Thriving in an increasingly digital ecosystem", MIT Sloan Management Review, Vol. 56 No. 4, p. 27.

[13]. Yoo, Y., Boland, R.J. Jr, Lyytinen, K. and Majchrzak, A. (2012), "Organizing for innovation in the digitized world", Organization Science, Vol. 23 No. 5, pp. 1398-1408.

[14]. Luca Di Persio, Oleksandr Honchar, Multitask machine learning for financial forecasting, International Journal of Circuits, Systems and Signal Processing, pp. 444-451, Volume 12, 2018.

[15]. Hamda Al Dhaheri, Sehjeong Kim, So-Yeun Kim, The Dynamics of Thalassemia Management in the United Arab Emirates, International
Journal of Biology and Biomedical Engineering, pp. 151-164, Volume 12, 2018.

[16]. Nunally, J. C., \& Bernstein, I. H. Psychometric theory. 1978. New York.

[17]. Cronbach, L. J. (1951). Coefficient alpha and the internal structure of tests. psychometrika, 16(3), 297-334

[18]. McGinnis, M.A. and Vallopra, R.M. (1999), "Purchasing and supplier involvement in process improvement a source of competitive advantage", Journal of Supply Chain Management, Vol. 35 No. 4, pp. 4250.

[19]. Porter, M.E. (1985), Competitive Advantage Creating and Sustaining Superior Performance, The Free Press, New York, NY.

[20]. Tracey, M., Vonderembse, M.A. and Lim, J.S. (1999), "Manufacturing technology and strategy formulation keys to enhancing competitiveness and improving performance", Journal of Operations Management, Vol. 17 No. 4, pp. 411-28

[21]. Roth, A. and Miller, J. (1990), "Manufacturing strategy, manufacturing strength, managerial success, and economic outcomes", in Ettlie, J., Burstein, M. and Fiegehaum, A. (Eds), Manufacturing Strategy, Kluwer Academic Publishers, Norwell, MA, pp. 97-108.

[22]. Skinner, W. (1985), "The taming of the lions how manufacturing leadership involved, 1780-1984", in Clark, K.B., Hayes, R. and Lorenz, C. (Eds), The Uneasy Alliance Managing the Productivity-Technology Dilemma, The Harvard Business School Press, Boston, MA, pp. 63-110

[23]. Vesey, J.T. (1991), "The new competitors they think in terms of speed-to-market", Academy of Management Executive, Vol. 5 No. 2, pp. 23-33. 


\section{Creative Commons Attribution License 4.0 (Attribution 4.0 International, CC BY 4.0)}

This article is published under the terms of the Creative Commons Attribution License 4.0

https://creativecommons.org/licenses/by/4.0/deed.en US 